\title{
Hogyan befolyásolja a primer szerkezet elágazó láncú polipeptidek* térszerkezetét és konjugátumaik funkcionális tulajdonságait?
}

\author{
HUDECZ Ferenc ${ }^{\mathrm{a}, \mathrm{b}}$ \\ ${ }^{a}$ ELTE Szerves Kémiai Tanszék, Pázmány Péter sétány 1A, H-1117 Budapest, Magyarország \\ ${ }^{b}$ MTA - ELTE Peptidkémiai Kutatócsoport, Természettudományi Kar, Kémiai Intézet, \\ Pázmány Péter sétány 1A, H-1117 Budapest, Magyarország
}

\section{Bevezetés}

Oláh György professzor nevével elöször a Szerves kémia előadáson találkoztam. Az ELTE TTK vegyész szakos hallgatójaként a II. év első félévében került sor a Szerves kémia tárgy (heti 4 óra) előadásaira. 1973 őszén Kucsman Árpád professzor, a főkollégium előadója az addiciós reakciók mechanizmusát elemezve mutatta be azt az eredményt, amelyet Dr. G. A. Olah nem sokkal előbb 1972-ben közölt (JACS 94: 808-820) és amely jelentős mértékben megalapozta a Nobel-díjat (1994). A 70-es évek szerves előadásai, az előadó törekvéseinek megfelelően, a szakmai minőség és a teljesítmény elismerése jegyében szóltak hozzánk. Később személyesen is találkoztam az MTA tiszteleti tagjával és örzöm a metanol-gazdasággal foglalkozó, magyarul 2007-ben megjelent kötetének egy dedikált példányát.

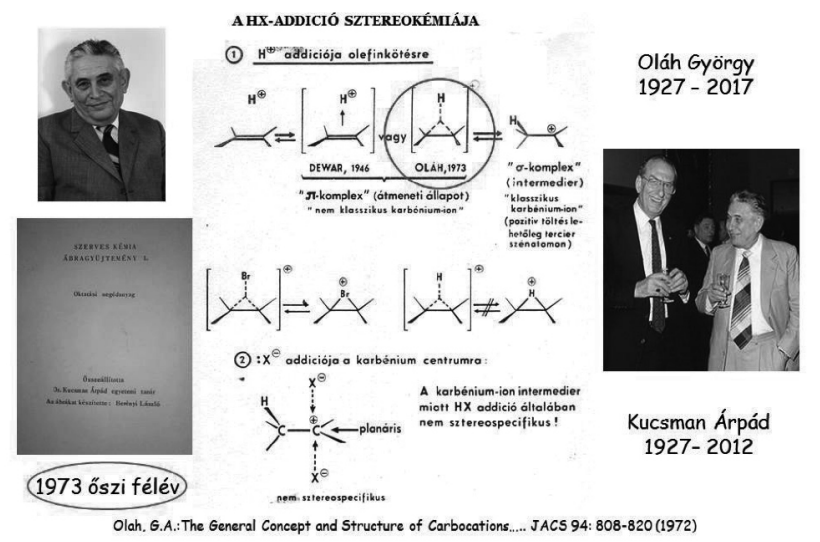

A biológiailag aktív elágazó láncú polimer polipeptidek kutatásának jelentős hazai hagyományai vannak az MTA-ELTE Peptidkémiai Kutatócsoportban. Sela és munkatársai 60 -as években közölt inspiráló eredményei ${ }^{1}$ és Szekerke Mária munkássága ${ }^{2}$ nyomán a kutatócsoport az 1970-es évektől foglalkozik polilizin gerincủ elágazó polipeptidek szintézisével, szerkezeti (kémiai) és funkcionális (biológiai) jellemzésével.
Az elmúlt évtizedekben közel 50 tagú új vegyületcsalád együttest állítottunk elö. A polipeptidek közös tulajdonsága, hogy bennük egy átlagosan 100-150, esetenként 200 lizin egységből álló polimer "gerinchez", a poli[L-Lys] homopolipeptidhez ugyancsak aminosavakból álló “oldalláncok" kapcsolódnak. Ezek az oldalláncok átlagosan 1-6 aminosavat tartalmaznak, egy, kettő vagy háromféle aminosavból épülnek fel és eltérnek egymástól az aminosav sorrend tekintetében is. Az oldalláncok a lizin egységek ع-amino csoportján egy rövid, 3-4 aminosavból álló oligo(DL-Ala) vagy oligo(DL-Ser) szakaszt és/vagy egy vagy kétféle optikailag aktív (L- vagy D-konfigurációjú) aminosavat (X és/vagy $U$ ) tartalmaznak. Az X és $U$ aminosav megválasztásával létre lehetett hozni különböző töltésü, töltéssürüségü, hidrofil/ hidrofób karakterü vegyületeket. ${ }^{3-16}$

Az MTA Kémiai Tudományok osztálya Oláh György emlékülésén (Budapest, 2017. május 3.) elhangzott előadás alapján készült jelen össze-foglaló áttekintést nyújt e vegyületek szintézisé-nek stratégiájáról, főbb lépéseiről és három különböző elágazó láncú vegyületcsoport tanulmá-nyozása során megfigyelt összefüggésekről. Példákon keresztül bemutatja, hogy a polipeptidek primer szerkezete (az aminosavösszetétel, az oldalláncok felépítése, a vegyület töltésviszonyai) miként befolyásolja az oldatbeli konformációt, az in vitro citotoxicitás mértékét, valamint a biodisztribució egy elemének (jelenlét a vérkeringésben) jellemzőit. További tájékozódást nyújthatnak a korábban közölt összefoglaló cikkek ${ }^{5,10,14}$ és az eredeti közlemények, amelyeket az irodalomjegyzék sorol fel.

Terjedelmi okok miatt e szöveg nem tér ki a szerkezet-hatás összefüggések teljes körének bemutatására, ezért csak utalhatunk arra, hogy az oldalláncok felépítése, különösen a láncvégi aminosavrész hidrofobicitása, a molekula töltésviszonyai és az oldatbeli konformáció meghatározóak a polipeptid foszfolipid modelmembránon kifejtett aktivitásában. 17-21 Dr. Rajnavölgyi Éva (ELTE Immunológia Tanszék) kutatásai alapján bizonyítást nyert, hogy állatkísérletekben az oldallánc aminosav összetétele, az oldalláncvégi, optikailag aktív aminosav konfigurációja

\footnotetext{
* Az elágazó láncú polipeptidek elnevezésénél a megfelelő szabályokat [IUPAC-IUB, 1984] alkalmaztuk. Az m index az oligo-DL-alanin láncok átlagos hosszát adja meg ( $\mathrm{pl} . \mathrm{m}=3$ ), az i pedig az X aminosav átlagos szubsztitúció fokát jelzi (i ??1). A vegyületek nevének rövidítésénél az amino-savak egybetüs kódját alkalmaztuk, azaz $\mathrm{K}=$ lizin, $\mathrm{A}=$ ala-nin, $\mathrm{X}=$ az oldalláncban szereplő aminosav. [IUPAC-IUB Commission on Biomedical Nomenclature. Eur. J. Biochem. 138, 9-37 (1984)].
} 
jelentősen befolyásolja a polipeptidek immunválaszt kiváltó képességét, az immunreakció sajátságait. ${ }^{22-24}$ Dr. Gaál Dezső (Országos Onkológiai Intézet) vizsgálatai szerint szerkezetüktől függően modulálják sejtes immungének által indukált immunválaszt, ellensúlyozni képesek tumorellenes kemoterápiás szerek (pl. vinkrisztin) vagy radioaktív sugárzás in vivo immunszuppresszív hatását. 25-27

\section{Az elágazó láncú polilizin gerincű polipeptidek szintézise, primer szerkezete és jellemzése}

A tárgyalt vegyületek három csoportjának vázlatos szerkezetét és egyes reprezentánsokat mutatja be az első három ábra (1-3. ábra). A poli[Lys $\left.\left(\mathrm{X}_{\mathrm{i}}-\mathrm{DL}-\mathrm{Ala}_{\mathrm{m}}\right)\right]^{*}$ (továbbiakban XAK) vegyületek csoportjában a poli[Lys] polimer polipeptidhez rövid oligo(DL-Ala) lánc kapcsolódik $\varepsilon$-amid kötéssel és annak $N$-terminálisán ( $\alpha$-amid kötés révén) helyezkedik el az $\mathrm{X}$ aminosav illetve acilezett (pl. Ac-Glu, Suc-Glu vagy Mal-Glu) származéka (1.ábra).

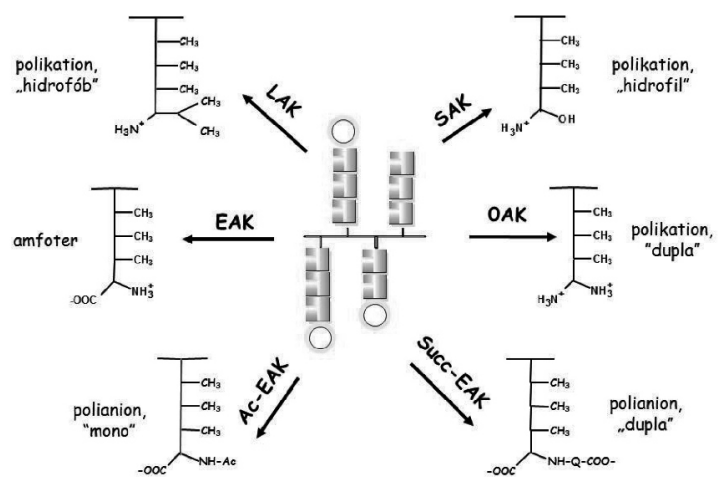

1. Ábra. A poli[Lys $\left.\left(\mathrm{X}_{\mathrm{i}}-\mathrm{DL}-\mathrm{Ala} \mathrm{a}_{\mathrm{m}}\right)\right]$ (továbbiakban $\mathrm{XAK}$ ) vegyületek, ahol $\mathrm{i}<1, \mathrm{~m} \sim 3-4$ és $\mathrm{X}=$ (D)Leu, Ile, Nle, Val, (D)Phe, (D)Tyr, Pro, (D)His, (D)Lys, Arg, Orn, Ser, Thr, (D)Glu, Ac-Glu, Suc-AK, Suc-Glu vagy Mal-Glu.

Az X aminosavat tartalmazó poli[Lys $\left.\left(\mathrm{X}_{\mathrm{i}}\right)\right]$ (továbbiakban $\mathrm{X}_{\mathrm{i}} \mathrm{K}$ ) típusú polipeptidekben az oldallánc rövid, csupán egyetlen $\mathrm{X}$ aminosavból áll (2. ábra), amelyet $\varepsilon$-savamid kötés rögzít a poli[L-Lys] gerinchez.

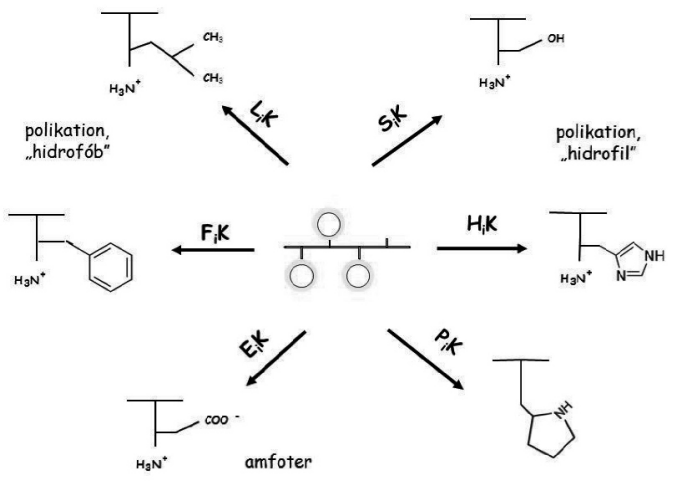

2. Ábra. A poli[Lys $\left.\left(X_{i}\right)\right]$ (továbbiakban $X_{i} K$ ) vegyületek, ahol $\mathrm{i}<1$ és $X$ =(D)Glu, (D)Leu, (D)Phe, (D)Ala, Ile, Pro, His, Ser
Az XAK vegyületekkel azonos aminosavakat tartalmazó, de fordított szekvenciájú oldalláncokkal rendelkeznek a poli[Lys(DL-Ala $\left.\mathrm{X}_{\mathrm{i}}\right)$ ] (továbbiakban $\mathrm{AXK}$ ) csoport tagjai (3.ábra).

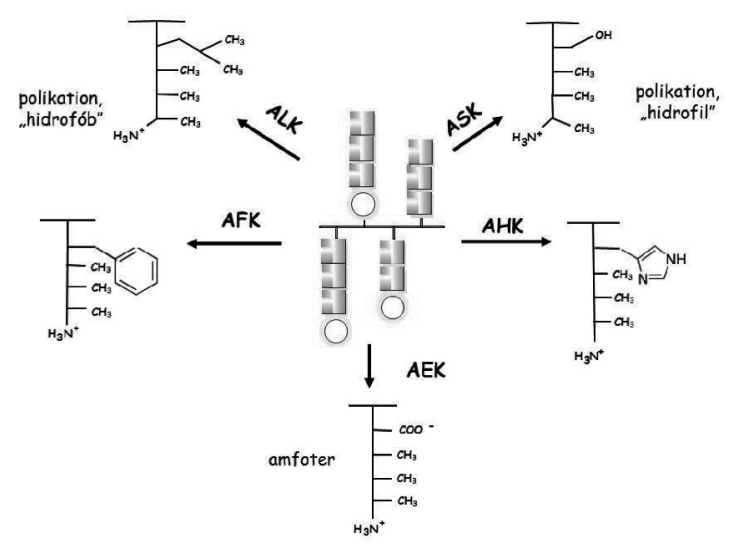

3. Ábra. A poli[Lys $\left(\mathrm{DL}-\mathrm{Ala}_{\mathrm{m}} \mathrm{X}_{\mathrm{i}}\right)$ ] (továbbiakban $\mathrm{AXK}$ ) vegyületek, ahol $\mathrm{i}<1, \mathrm{~m} \sim 3-4$ és $\mathrm{X}=(\mathrm{D})$ Leu, Phe, Pro, His, Ser, (D)Glu.

Említést érdemel, bár ebben az összefoglalóban nem kerül részletes tárgyalásra, hogy készültek az oldalláncvégeken Lys-Lys, Glu-Glu vagy Tyr-Tyr dipeptidet illetve átlagosan három aminosavból Lys vagy Glu peptidszakaszt tartalmazó variációk is.

A Kutatócsoportban az évek során a kidolgozott és optimalizált szintézis stratégiát, annak gondolatmenetét mutatja be a 4.ábra.

A poli[L-Lys] polipeptidláncot L-Lys(Z)-NCA dietilamin iniciált polimerizációjával előállítottuk elő. Az N-karboxi anhidrid szintézise L-Lys(Z)-OH származék és korábban foszgén, ${ }^{3,4}$ majd trifoszgén felhasználásával, optimalizált körülmények kimunkálásával valósult meg. ${ }^{16}$

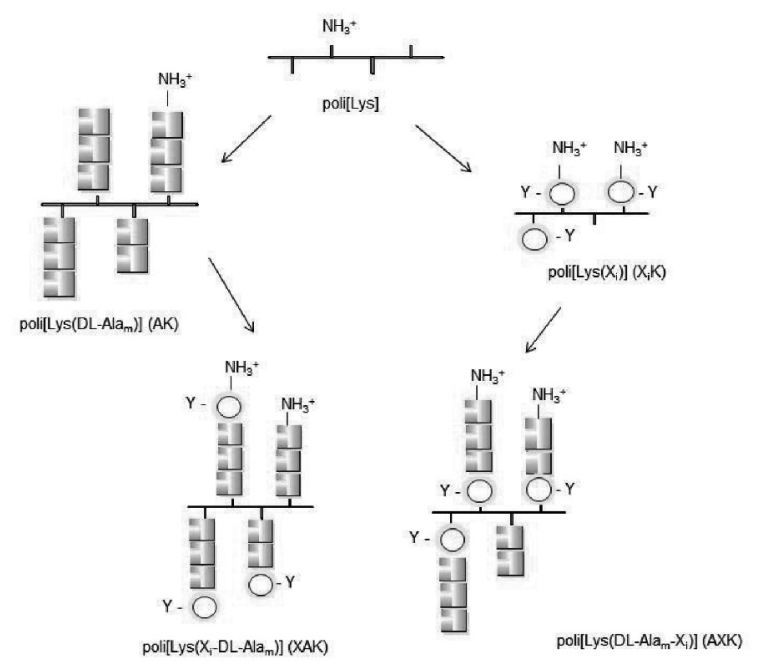

4. Ábra. A poli[Lys $\left.\left(\mathrm{X}_{\mathrm{i}}-\mathrm{DL}-\mathrm{Ala} \mathrm{a}_{\mathrm{m}}\right)\right](\mathrm{XAK})$, a poli $\left[\mathrm{Lys}\left(\mathrm{X}_{\mathrm{i}}\right)\right]\left(\mathrm{X}_{\mathrm{i}} \mathrm{K}\right)$ és a poli[Lys $\left(\mathrm{X}_{\mathrm{i}}\right.$-DL-Ala $\left.\left.\mathrm{m}_{\mathrm{m}}\right)\right](\mathrm{AXK})$ vegyületek, ahol $\mathrm{i}<1, \mathrm{~m} \sim 3-4$. szintézisének stratégiája. 
Az XAK típusú polipeptidek előállításakor először eltávolítottuk az $\mathrm{N}^{\varepsilon}-\mathrm{Z}$ védőcsoportokat ( $\mathrm{HBr} /$ jégecet), majd a poli[L-Lys] szabad $\mathrm{N}^{\varepsilon}$-amino csoportjai reagáltak DL-Ala NCA-val úgy, hogy átlagosan 3-4, esetenként hosszabb (6-9) aminosavból álló oligo(DL-Ala) oldalláncok jöjjenek létre. $\mathrm{Az}$ így kialakított poli[Lys(DL-Ala $\mathrm{m})$ ] $(\mathrm{AK})$ oldalláncok $N$-terminálisához konjugáltuk a védett $\mathrm{X}$ aminosavat aktív észteres kapcsolással HOBt kapcsolószer jelenlétében. ${ }^{3,4,11}$ $\mathrm{Az}$ Arg tartalmú polipeptideknél a guanidino- $\mathrm{NO}_{2}$ védőcsoport szelektív hasítására új módszer kidolgozására is sor került: $\mathrm{NaBH}_{4}$ segítségével, réz komplex katalizátor jelenlétében. ${ }^{16}$ A védőcsoportoktól mentes Glu tartalmú polipeptid acilezésével állítottunk elő polianionos (Ac-EAK, Suc-EAK, Mal-EAK) származékokat. 9, 15

Az $\mathrm{X}_{\mathrm{i}} \mathrm{K}$ típusú polipeptidek szintézisénél, $\mathrm{N}^{\varepsilon}-\mathrm{Z}$ védőcsoport eltávolítását követően a polilizin $\mathrm{N}^{\varepsilon}$-amino csoportjaihoz az $\mathrm{N}^{\alpha}$-amino csoporton és szükség esetén az $\mathrm{X}$ aminosav oldalláncán (pl. Glu $\gamma$-COOH csoport) védett - aminosavat [pl. Z-Glu(OBzl)]kapcsoltunk aktív észteres módszerrel, majd a védőcsoporto(ka)t eltávolítottuk $\mathrm{HBr} / \mathrm{jégecet}$ kezeléssel. ${ }^{\text {6-8,11 }}$

Ez a polipeptid $\left(\mathrm{X}_{\mathrm{i}} \mathrm{K}\right)$ szolgált iniciátorként az $\mathrm{AXK}$ típusú polimer polipeptidek szintéziséhez, amikor $\mathrm{N}^{\alpha}$-karboxi-DLAla anhidrid (DL-Ala NCA) felhasználásával 3-4 aminosavból álló oligo(DL-Ala) oldalláncot alakítottunk ki (4.ábra). ${ }^{6-8,11}$

Megjegyzendő, hogy sor került SK és XSK (ahol X = Leu vagy Glu) típusú polipeptidek előállítására is. Ekkor a poli[L-Lys] $\mathrm{N}^{\varepsilon}$-amino csoportjai DL-Ala NCA helyett $\mathrm{N}^{\alpha}$-Z-DL-Ser(Bzl) anhidriddel reagáltak úgy, hogy a kívánt hosszúságú oligo(Ser) oldalláncok jöjjenek létre. A védett poli[Lys(DL-Ser $\left.{ }_{\mathrm{m}}\right)$ (SK) polipeptid $\mathrm{N}^{\alpha}$-amino csoportjaihoz ezután került sor az X aminosav megfelelö származékának kapcsolására, majd a benzil-éter védőcsoportok lehasítására. ${ }^{11-13}$

Az oldalláncok összetételének, az aminosavak konfigurációjának (L/D) módszeres változtatásával egymással rokon, de kisebb-nagyobb mértékben eltérő szerkezettel (pl. töltés, hidrofilitás) jellemezhető polimer polipeptidek kerültek előállításra (1-3. ábrák). ${ }^{14-16}$ A primer szerkezet és a méret minden korábbinál pontosabb leírása során meghatározták a polipeptidek méreteloszlását (szedimentációs analízis, gélpermeációs kromatográfia, újabban tömegspektrometria. ${ }^{\text {28-30}}$ ) és összetételét (aminosavanalizis és végcsoportanalízis), az oldalláncok hosszúság-eloszlását és enantiomer-összetételét. ${ }^{31-33}$

\section{Térszerkezet - az oldatbeli konformáció jellemzése}

A polimer polipeptidek konformációs tulajdonságait cirkuláris dikroizmus (CD) spektroszkópiával jellemeztük. Az első oldatbeli térszerkezet vizsgálatokra Dr. Karel Blaha kutatócsoportjában, Prágában (Institute of Organic Chemistry and Biochemistry, Czechoslovak Academy of Sciences) került sor. ${ }^{34}$
A módszer nagy előnye, hogy segítségével ér-zékenyen detektálható a környezeti tényezők (pH, ionerősség, oldószer polaritása, hőmérséklet stb.) konformációt befolyásoló hatása. A polipeptidek $\mathrm{CD}$ spektrumait különböző kémhatású [savas (pH 3), közel semleges ( $\mathrm{pH} \sim 7,4)$, bázikus $(\mathrm{pH} \sim 12)]$, ionerősségü $(0,02,0,2,2,0 \mathrm{M}$ $\mathrm{NaCl}$ ) illetve alkohol tartalmú (TFE illetve $\mathrm{MeOH}, 100 \%$, $75 \%, 50 \%), \mathrm{c}=0,5-1,0 \mathrm{mg} / \mathrm{cm}^{3}$ koncentrációjő oldószerben. A $\Delta \varepsilon$ illetve $[\theta] \mathrm{MR}$ értékeket a fölánc egy lizin egységére vonatkoztatva állapítottuk meg beleértve a teljes oldalláncot. Példaként az AK polipeptid - különböző körülmények között felvett - spektrumait mutatja be az 5. ábra.
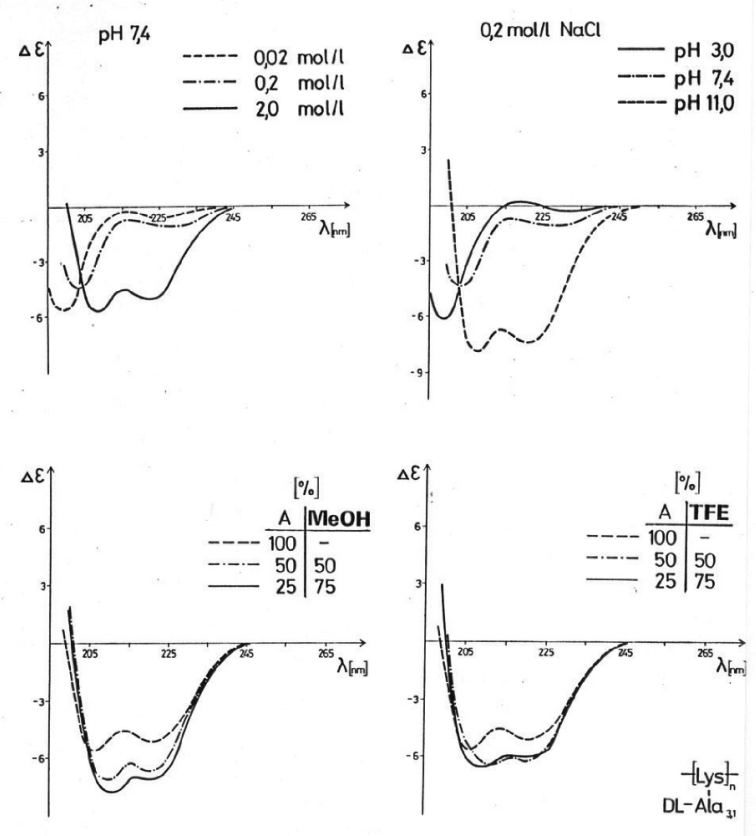

5. Ábra. A poli[Lys $\left.\left(\mathrm{DL}-\mathrm{Ala}_{\mathrm{m}}\right)\right]$ (AK) polipeptid, ahol $\mathrm{m} \sim 3-4 \mathrm{CD}$ spektrumai különböző ionerősségü $(0.02 \mathrm{M}, 0.2 \mathrm{M}, 2.0 \mathrm{M} \mathrm{NaCl})$, kémhatású ( $\mathrm{pH}$ 3, 7.4 vagy 11) és alkohol tartalmú vizes oldatban

A környezeti hatások feltérképezése lehetővé teszi a polipeptid konformációjának jellemzését, az elsődleges szerkezet és a térszerkezet közötti összefüggések tanulmányozását. Összehasonlító elemzésekből következtetéseket vontunk le a töltés, a hidropátiás tulajdonságok konformációt befolyásoló hatására vonatkozóan. ${ }^{5-8,10-14,16,34-36}$

A spektrumok interpretációja a lineáris homopolimer polipeptidek, elsősorban a poli[L-Lys] spektrumán alapul (6. ábra). ${ }^{37,38} \mathrm{Az} \alpha$-helikális szerkezet három abszorpciós maximummal jellemezhető: negatív sáv $(\lambda=222-224 \mathrm{~nm})$, amely az $n-\pi *$ átmenethez rendelhetö, azonos intenzitású negatív sáv $(\lambda=206-208 \mathrm{~nm})$ és egy pozitív sáv a $(\lambda=191$ $\mathrm{nm})$, amelyek a $\pi-\pi^{*}$ átmenethez tartoznak. Az n- $\pi^{*}$ sáv intenzitása csak kis mértékben függ a helikális szakasz hosszától, míg a $\pi-\pi^{*}$ sávpár intenzitása erősen függ a szakaszt alkotó aminosavak számától. A rendezetlen konformáció spektruma, vizes, sómentes oldatokban egy gyenge pozitív maximumot $(\lambda=217-218 \mathrm{~nm})$, és egy 
intenzív negatív maximumot $(\lambda=196-198 \mathrm{~nm})$ mutat, nagy sókoncentráció esetén egy gyenge $(\lambda=220-225 \mathrm{~nm})$ és egy erős negatív maximum $(\lambda=190-205 \mathrm{~nm})$ észlelhető. A $\beta$-szerkezet spektruma egy negatív maximum $(\lambda \sim 215 \mathrm{~nm})$ és egy intenzívebb pozitív maximum $(\lambda \sim 205 \mathrm{~nm})$ jellemzi.

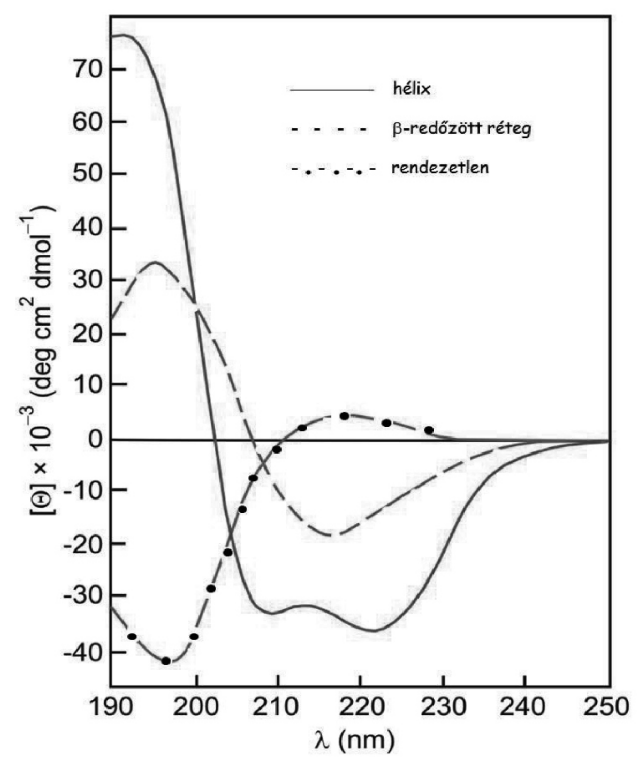

6. Ábra. A poli[L-Lys] CD spektrumai és a görbék értelmezése ${ }^{37,38}$

Az alábbiakban példák segítségével bemutatásra kerül a) miként befolyásolja az $\mathrm{X}$ aminosav minemüsége és annak pozíciója az oldatbeli 3D szerkezetet, b) milyen jellemző struktúrák jöhetnek létre a fiziológiás körülmények között (pH 7,4, 0.2 M NaCl).

\subsection{Az oldallánc $N$-terminálisán elhelyezkedő $\mathrm{X}$ aminosav minemúségének szerepe}

A DL-Ala $\mathrm{m}$ (AK) illetve X-DL-Ala $\mathrm{m}$ (XAK) oligopeptid oldalláncok $N$-terminálisán elhelyezkedő aminosavak közös sajátsága (a Pro kivételével), hogy $\alpha-\mathrm{NH}_{2}$ csoportot tartalmaznak. Ennek következtében e vegyületek savas ( $\mathrm{pH}$ 3) és közel semleges $(\mathrm{pH} \sim 7,4)$ körülmények között pozitív töltésüek, míg bázikus oldatban $(\mathrm{pH} \sim 12)$ nem viselnek töltést. Ez magyarázhatja azt a megfigyelést, amely szerint a vizes oldat $\mathrm{pH}$ értékének növelése a rendezett térszerkezet kialakulásának kedvez.
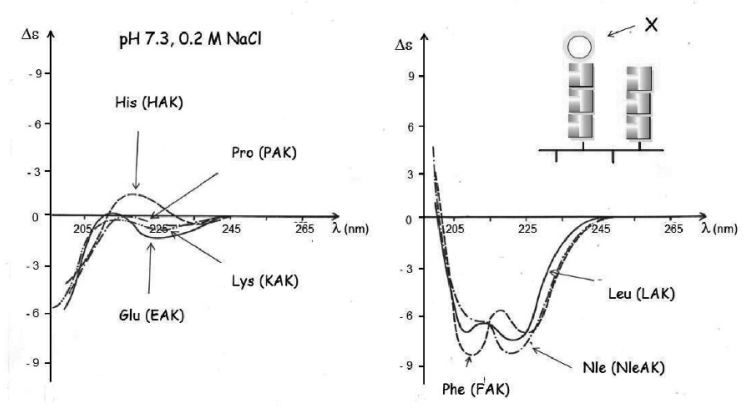

7. Ábra. A poli[Lys $\left.\left(\mathrm{X}_{\mathrm{i}}-\mathrm{DL}-\mathrm{Ala}_{\mathrm{m}}\right)\right]$ vegyületek, ahol $\mathrm{i}<1, \mathrm{~m} \sim 3-4$ és $\mathrm{X}=\mathrm{His}$, Lys, Glu, Pro illetve Leu, Nle, vagy Phe CD spektruma közel fiziológiás ionerősségü $(0.2 \mathrm{M} \mathrm{NaCl})$ és kémhatású ( $\mathrm{pH} 7.4)$ vizes oldatban.
Az ionerősség emelése elősegíti a polipeptid rendezett, döntően $\alpha$-helikális konformációjának kialakulását (6. ábra). Fehérjékre leirt irodalmi adatok szerint a TFE megjelenése a vizes oldatban a rendeződésnek kedvez. Adataink ezt megerősítették a szintetikus polipeptidek vonatkozásában és bizonyítást nyert, hogy e sajátsággal rendelkezik más alkohol (pl. $\mathrm{MeOH})$ is. ${ }^{\mathbf{3 4 - 3 6}}$

A kísérletek azt mutatták, hogy a közel fiziológiás ( $\mathrm{pH} \sim 7,4$, $0,2 \mathrm{M} \mathrm{NaCl}$ ) oldatban az aminosavoldalláncban töltéssel bíró $N$-terminális aminosavak (X = His, Lys, Orn, Glu) jelenléte rendezetlen térbeli elrendeződést eredményez ( 7 . ábra). Ugyanakkor a hidrofób aminosav-oldalláncú aminosavak karakterétől (lineáris, elágazó, aromás) függő mértékben, az X = Leu, Ile, Nle, Val, Phe, Tyr tartalmú polipeptidek alapvetően rendezett konformációt vesznek fel (7. ábra). ${ }^{16,34-36}$ Fontos az a megfigyelés is, amely szerint Ser vagy Thr tartalmú polipeptidek (SAK, TAK) CD spektumai részben rendezett konformációra illetve a rendezett és rendezetlen konformerek elegyére utalnak. ${ }^{11}$

Érdemes felhívni a figyelmet arra, hogy - fenti körülmények között - a Leu (LAK), Ile (IAK), Nle (NleAK) vagy Val (VAK) jelenléte egymáshoz hasonló CD spektrumokat eredményez, de esetenként a kimutatható konformek elegye eltérő összetételü lehet. Például, a Val tartalmú polipeptid (VAK) részben $\alpha$-hélix és részben $\beta$-kanyar konformert hoz létre, míg a Nle tartalmú vegyület (NleAK) CD spektrumában a $\beta$-kanyar konformer és rendezetlen szerkezet mutatható ki. A különbség értelmezésénél az alkil oldalláncok különbözősége, a hidrofób kölcsönhatás erőssége játszhat szerepet. ${ }^{\mathbf{1 6}}$

Újabb eredményeink arra is utalnak, hogy rendezett konformáció létrehozható kationos oldalláncú $(\mathrm{X}=\mathrm{Arg})$ aminosav beépítésével (RAK) is. A hidrofób oldalláncú Ile (IAK) és a guanidino csoportot tartalmazó Arg (RAK) CD spektrumainak összevetése azonos körülmények között ( 8 . ábra) jelzi, hogy a $\mathrm{pH}$ változása a lúgos tartomány irányába (pH 3 - pH 7,4 - pH 12) mindkét elágazó láncú polipeptid esetében a rendezett konformáció domináns jelenlétét eredményezi. ${ }^{16}$

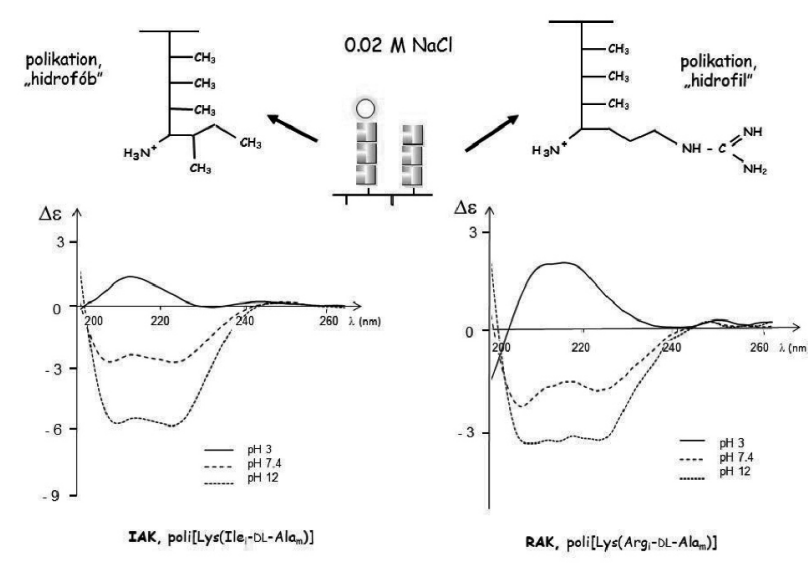

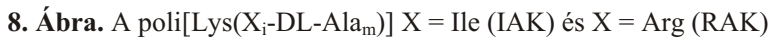
polipeptidek, ahol i $<1, \mathrm{~m} \sim 3-4 \mathrm{CD}$ spektrumai különböző kémhatású (pH 3, 7.4 vagy 12), 0,02 $\mathrm{M} \mathrm{NaCl}$ ionerösségü vizes oldatban. 
Kiemelést érdemel, hogy az arginin tartalmú polipeptid (RAK) CD spektrumai - meglepő módon - az $N$-terminálison hidrofób oldalláncú izoleucint tartalmazó vegyület (IAK) spektrumával mutat hasonlóságot és nem a szintén kationos, láncvégén Lys aminosavat tartalmazó polipeptiddel (KAK) (lásd 7. és 8. ábra).

Megállapítható tehát, hogy a vizsgált kationos, elágazó láncú, XAK típusú, polipeptidek esetében mind a magasabb pH érték (savas vs bázikus), mind a növekvő ionerősség a rendezett, jellemzően helikális szerkezet kialakulásához vezet. Az oldalláncvégi $\alpha-\mathrm{NH}_{2}$ csoportok csökkenő protonáltsága, illetve az növekvő ionkoncentráció ,árnyékoló” képessége rendezett szerkezetet alakít ki.

Ha az $N$-terminális $\mathrm{X}$ pozicióban levő glutaminsavat acetilezzük (Ac-EAK) vagy szukcinilezzük (Suc-Glu) különböző töltéssürüségű - polianionos vegyületekhez jutunk. ${ }^{9,15} \mathrm{Az}$ azonos körülmények között rögzített $\mathrm{CD}$ spektrumok (9. ábra) jelzik, hogy míg az amfoter sajátságú EAK görbéje rendezettsége utal, a csak negatív töltést hordozó származékokra a rendezetlenségre jellemző. Ez értelmezhető a monomer egységenként egy (Ac-EAK) illetve két (Suc-EAK) negativ töltés taszító hatásával.

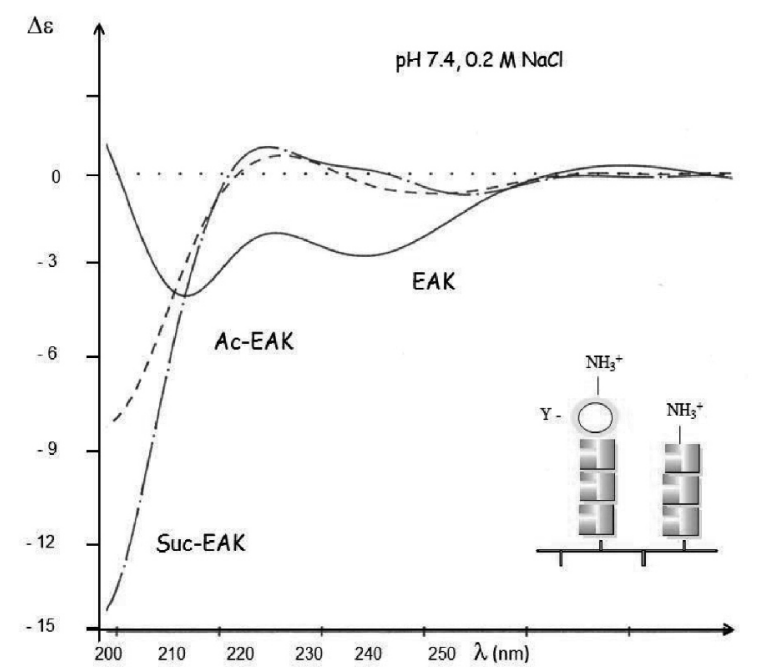

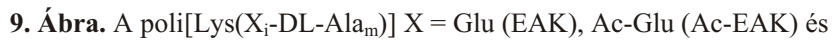
Suc-Glu (Suc-EAK) polipeptidek, ahol i $<1, \mathrm{~m} \sim 3-4$ CD spektrumai vizes oldatban $(\mathrm{pH} 7.4,0,2 \mathrm{M} \mathrm{NaCl})$.

Összegezve megállapítható, hogy az XAK típusú elágazó láncú polipeptidek oldatban rendezett konformációt hozhatnak létre. Ennek hátterében lehet az oldallánc végi $\mathrm{X}$-aminosavak között fellépő intramolekuláris ionos (pl. Arg, Glu), hidrofób (pl. Leu, Nle), valamint a H-híd kölcsönhatás (pl. Ser, Thr). A jelenség értelmezése az oldalláncok közötti kölcsönhatások kombinációjához és ezek erősségéhez köthető. Ennek felismerése lehetővé teszi az adott körülmények között kívánatos konformációjú vegyület tervezését. $5,10,14,16,34-36$

\subsection{Az oldalláncban elhelyezkedő $\mathrm{X}$ aminosav poziciójának szerepe}

Az X aminosav oldalláncban elfoglalt helye befolyásolhatja a térszerkezetet. Ennek vizsgálatára a fenti módszertan szerint felvett CD spektrumok összehasonlító elemzése történt meg. Az XAK és AXK típusú polipeptid párok $(\mathrm{X}=$ Leu vagy $\mathrm{Phe}$ ) esetében azt tapasztalható, hogy a rendezett konformáció kialakulásának körülményeit az X aminosav oldallánc milyensége és az oligopeptid oldalláncban elfoglalt helye határozza meg. Például Leu kapcsolódása közvetlenül a polilizin gerinc $\varepsilon$-amino csoportjához (ALK) rendezett ( $\alpha$-hélix)
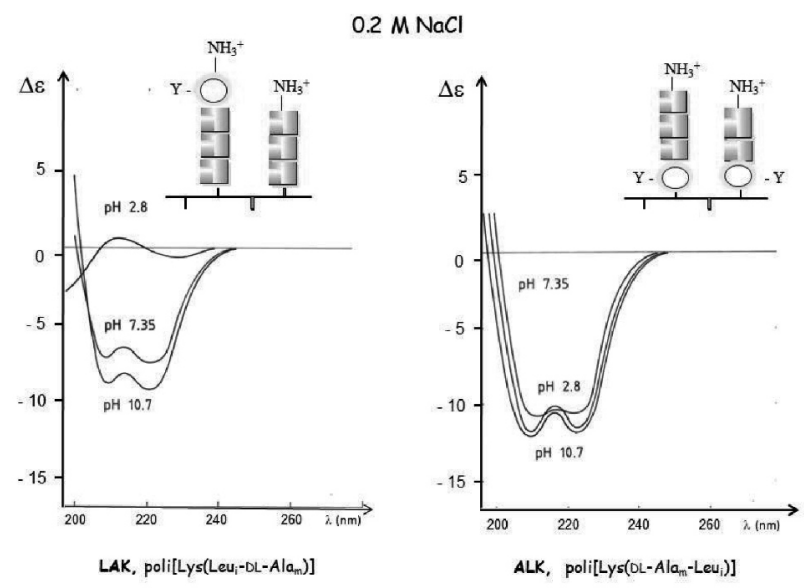

10. Ábra. A poli[Lys $\left.\left(\mathrm{Leu}_{\mathrm{i}}-\mathrm{DL}-\mathrm{Ala}_{\mathrm{m}}\right)\right](\mathrm{LAK})$ és a poli[Lys(DL-Ala $\mathrm{Leu}_{\mathrm{i}}$ ) (ALK) polipeptid, ahol ahol i $<1, \mathrm{~m} \sim 3-4 \mathrm{CD}$ spektrumai különbözö kémhatású ( $\mathrm{pH} 3,7.4,10,7), 0.2 \mathrm{M} \mathrm{NaCl}$ tartalmú vizes oldatban

konformációhoz vezet savas, alacsony ionerősségü $0.02 \mathrm{M}$ $\mathrm{NaCl}$ oldatban, míg a Leu jelenléte az oligopeptid oldallánc $N$-terminálisán (LAK) - azonos körülmények között rendezetlen térszerkezetet eredményez (10. ábra).

Érdemes megjegyezni, hogy ez a markáns különbség lényegében eltünik, ha az oldat $\mathrm{pH}$ értékét emelik. Semleges vagy bázikus oldatban mindkét polipeptid kifejezetten rendezett konformációra utaló CD spektrumot mutat (10. ábra). Hasonló viselkedésbeli különbség volt tapasztalható az FAK vs AFK polipeptid pár esetében ( $\mathrm{pH} 3.0,0.02 \mathrm{M}$ $\mathrm{NaCl}){ }^{6}$

Az SAK és ASK polipeptidek oldalláncai protonáltak savas (pH 2.1, $0.02 \mathrm{M} \mathrm{NaCl)} \mathrm{vizes} \mathrm{oldatban} \mathrm{és} \mathrm{mindkét}$ vegyület konformációja rendezetlen. A pH emelésére ( $\mathrm{pH}$ 7.2) egyformán reagálnak és részben rendezett konformáció jelenik meg. Ugyanakkor az ionerősség növelése $(0.2 \mathrm{M} \mathrm{NaCl})$ és/vagy a $\mathrm{pH}$ további emelése szemben az ASK polipeptiddel - az SAK polipeptid esetében markáns hélix-tartalom (rendezettség) növekedésével járt (11. ábra). 


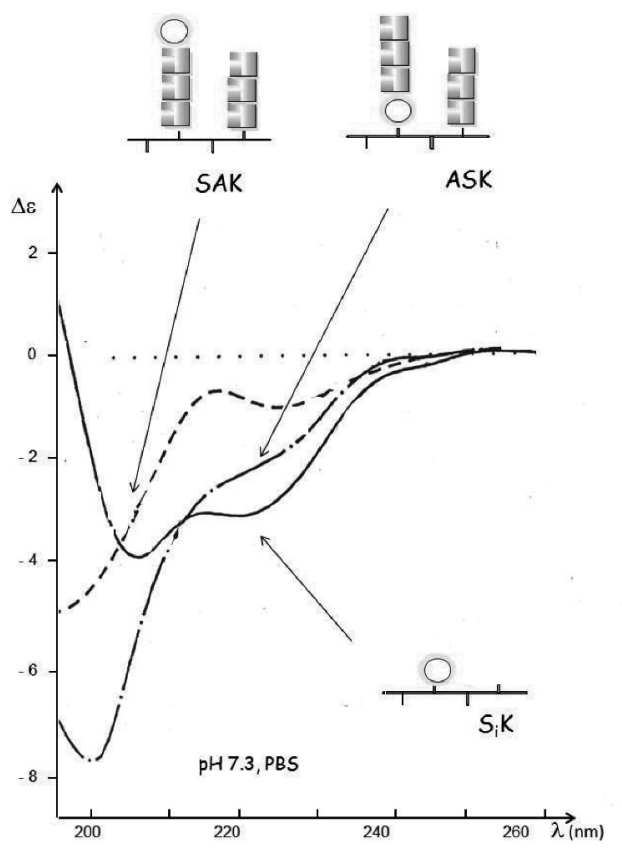

11. Ábra. A poli[Lys $\left.\left(\operatorname{Ser}_{\mathrm{i}}-\mathrm{DL}-\mathrm{Ala}_{\mathrm{m}}\right)\right](\mathrm{SAK})$, a poli $\left[\mathrm{Lys}\left(\mathrm{DL}_{\mathrm{L}}-\mathrm{Ala}_{\mathrm{m}}-\mathrm{Ser}_{\mathrm{i}}\right)\right.$ (ASK) polipeptid és a poli[Lys $\left.\left(\mathrm{Ser}_{\mathrm{i}}\right)\right]\left(\mathrm{S}_{\mathrm{i}} \mathrm{K}\right)$, ahol ahol $\mathrm{i}<1, \mathrm{~m} \sim 3-4 \mathrm{CD}$ spektrumai (pH 7.4) $0.2 \mathrm{M} \mathrm{NaCl}$ tartalmú vizes oldatban.

Ez arra utalhat, hogy a polilizin gerinchez közeli pozícióban a Ser jelenléte kevésbé segíti elő a rendezett konformáció kialakulását, míg a távolabbi (az oligopeptid oldallánc $N$-terminálisán) pozíció markáns rendezettséghez vezet. ${ }^{\mathbf{1 1 , 1 2}}$ Ezt az interpretációt finomítja az SAK, ASK és $\mathrm{S}_{\mathrm{i}} \mathrm{K}$ polipeptidek fiziológiás körülmények között felvett $\mathrm{CD}$ spektrumainak összehasonlító elemzése (11. ábra). Az $\mathrm{S}_{\mathrm{i}} \mathrm{K}$ polipeptid spektrumának lefutása arra utal, hogy a vegyület jelentős mértékben rendezett. A rendezettség kialakításában szerepet játszó (az $\mathrm{OH}$ csoport jelenlétével összefüggő) H-híd kötés markáns hatását „lerontja” a Ser aminosavhoz $\left(\mathrm{S}_{\mathrm{i}} \mathrm{K}\right)$ kapcsolt oligo(DL-Ala) oldallánc. ${ }^{12}$

A Glu tartalmú polipeptidek ECD spektrumainak összehasonlítása arra utal, hogy a glutaminsav jelenléte a polilizin gerinc közvetlenül kapcsolva $\left(\mathrm{E}_{\mathrm{i}} \mathrm{K}\right)$ savas kémhatású oldatban ( $\mathrm{pH}$ 2) már alacsony ionerősség esetén $(0.02 \mathrm{M} \mathrm{NaCl})$ részleges rendezettséget eredményez, amelynek mértéke nő az ionerősség növelésével (0.2 illetve 2.0 M NaCl). Az oligo(DL-Ala) oldalláncokkal kiegészitett polipeptid (AEK) ezzel ellentétben csak magasabb ionerösség ( $0.2 \mathrm{M} \mathrm{NaCl}, \mathrm{pH} 2.1)$ esetén mutat részleges rendezettséget. Ugyanakkor az oldallánc $N$-terminálisán szereplő Glu (EAK) a teljes pH tartományban $(1.1$ - 9.7) rendezetlen $(0.2 \mathrm{M} \mathrm{NaCl}$ oldatban) és csak a legmagasabb ionerősség $(2.0 \mathrm{M} \mathrm{NaCl})$ képes rendezettséget kiváltani.

Az amfoter EAK és AEK (valamint az $\mathrm{E}_{\mathrm{i}} \mathrm{K}$ ) polipeptidek oldalláncai töltést viselnek a teljes $\mathrm{pH}$ tartományban. Savas közegben az $\alpha$-amino csoportok protonáltak, míg bázikus közegben a $\gamma$-karboxil csoportok viselnek negatív töltést. Vizes oldatban, a körülmények ( $\mathrm{pH}$ és ionerősség) térszerkezet befolyásoló hatása az $\alpha$-amino és a $\gamma$-karboxil csoportok közötti ionos kölcsönhatás létrejöttével lehet összefüggésben. Ezen ionos kölcsönhatás pedig jelentős mértékben attól függ, hogy a polipeptid oldalláncban a Glu aminosav ( $\gamma$-karboxil) térben hol helyezkedik el: közelebb (EAK) vagy távolabb (AEK) a polipeptid oldalláncvégi $\alpha$-amino csoporthoz képest. ${ }^{8}$

Összegezve elmondható, hogy az elágazó láncú polipeptidek térszerkezetét az oldallánc felépítése: az X aminosav poziciója, oldalláncának hidrofób karaktere, heteroatom, ionizálható csoport jelenléte együttesen befolyásolja.

A rendezett, rendszerint $\alpha$-helikális konformáció, kialakulását, stabilizálódását elősegítheti az apoláros aminosav alkil vagy aril oldalláncok közötti hidrofób kölcsönhatás (XAK vs AXK polipeptidek X= Leu, Phe), az ionos kölcsönhatás a Glu $\gamma$-karboxil és az oldalláncvégi $\alpha$-aminocsoport (EAK vs AEK) vagy H-híd kötés a Ser hidroxil csoport és a polipeptid oldalláncvégi $\alpha$-aminocsoport között (SAK vs. ASK). Fontos hangsúlyozni, hogy a kölcsönhatás mértéke, s így a térszerkezetre gyakorolt hatása függ a partnerek közötti távolságtól. Az eredmények arra utalnak, hogy a fenti típusú, az X aminosav jelenlétével összefüggő kölcsönhatások - az adott körülmények ( $\mathrm{pH}$, ionerősség, oldószer) - erősebbnek bizonyultak, mind a polipeptid oldalláncok végén elhelyezkedő $\alpha$-aminocsoportok közötti taszító hatás.

\section{Szerkezet - in vitro citotoxicitás}

A következő példák segítségével röviden bemutatjuk, hogy milyen összefüggést állapítottunk meg a különböző sejteken megfigyelt in vitro citotoxicitás/citosztatikus hatás mértéke, valamint a szervezetbeli eloszlás (biodisztribució) sajátosságai és a kémiai szerkezet között.

A polipeptidek in vitro citotoxicitását izolált patkány máj-, egér lépsejteken ${ }^{26}$, egér csontvelői eredetü makrofág sejteken ${ }^{15}$ illetve Balb/c eredetü J774 monocita-makrofág sejtvonal ${ }^{39}$ sejtjein vizsgáltuk. A citosztatikus tulajdonságot C26 egér vastagbél carcinoma ${ }^{12}$, HeLa humán carcinoma 23,24, HT-29 humán (ATCC HB-8065) ${ }^{40}$ és HepG2 humán hepatocelluláris carcinoma (ATCC HTB-38) ${ }^{\mathbf{4 0}}$ sejtek szaporodására gyakorolt gátló hatással jellemeztük.

A polipeptideket izolált patkány máj- vagy egér lépsejtekkel inkubáltunk (1 és 24 óra, $37^{\circ} \mathrm{C}, \quad 1,5-50 \mu \mathrm{g} / \mathrm{ml}$ koncentrációtartomány). ${ }^{12,}$ 24, 26 Az élo sejtek arányát (\%) határoztuk meg a kezeletlen kontrolhoz képest (12. Ábra).

A polipeptidek toxikus hatását izolált májsejtekre nagymértékben befolyásolta az oldalláncában eloforduló $\mathrm{X}$ aminosav minemusége. A szabad $\varepsilon$-aminocsoportokat $\left(\mathrm{pK}_{\mathrm{a}}\right.$ $=10,53$ ) hordozó poli[L-Lys] - és nagyobb mértékben $-\mathrm{a}$ poli[D-Lys], valamint az oldallánc végén lizint tartalmazó változat $(\mathrm{KAK})$ toxikusnak bizonyult. Ezzel szemben a szabad $\alpha$-aminocsoportokat hordozó poli[ $\varepsilon$-Lys)] lényegesen kisebb mértékben csökkentette a sejtek életképességét. ${ }^{24,26}$ 
Az amfoter (EAK), a polianionos (Ac-EAK, Suc-EAK) polipeptidek vagy az oldalláncban hidroxil csoportot (SAK, $\mathrm{S}_{\mathrm{i}} \mathrm{K}$ ) tartalmazó polikationos vegyületek nem csökkentették az élo sejtek számát. ${ }^{12,} 24$ Ehhez hasonlóan a polikationos polipeptidek ( $\mathrm{X}=$ Leu, Phe, His,Pro) sem mutattak markáns citotoxikus hatást $(<5 \%)$.

Érdemes megjegyezni, hogy az oligo(DL-Ala) oldallánc hossza $(\mathrm{m}=3,5$ vagy 8,5$)$ befolyásolja a sejtszám csökkenés mértékét. Fontos megfigyelésünk, hogy az oldalláncban sem az $\mathrm{X}$ aminosav pozíciója (EAK/AEK, SAK/ASK, LAK/ALK), sem pedig az $\mathrm{X}$ aminosav konfigurációja (pl. EAK/D-EAK, LAK/D-LAK, FAK/D-FAK, KAK/D-KAK, HAK/D-HAK) nem befolyásolta az effektus mértékét. ${ }^{10,12,24}$

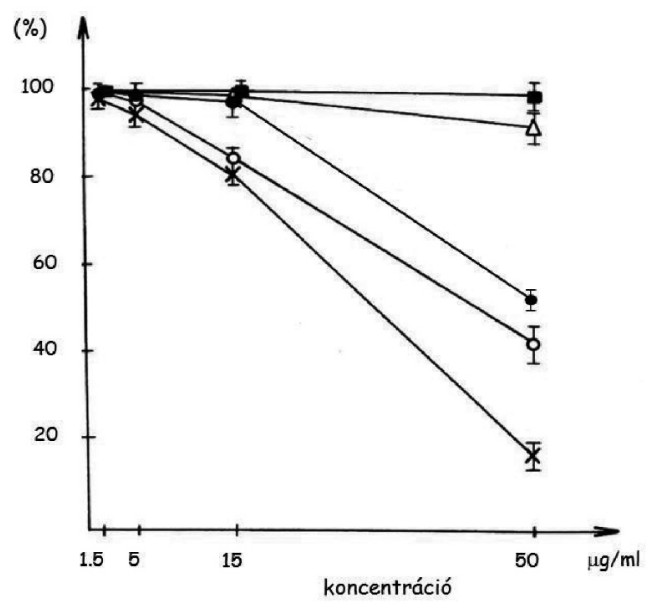

12. Ábra. A poli[Lys], poli[Lys(Lys)], poli[Lys(DL-Ala $\left.\left.\mathrm{L}_{\mathrm{m}}\right)\right]\left(\mathrm{A}_{\mathrm{m}} \mathrm{K}\right)$, továbbá XAK és AXK tipusú polipeptidek in vitro citotoxicitása. Izolált patkány májsejtek viabilitása a koncentráció függényében (inkubálás: 1 óra, $37^{\circ} \mathrm{C}$ ), ahol = EAK, AEK, SAK, ASK, $\Delta=\mathrm{LAK}, \mathrm{ALK}, \mathrm{D}-\mathrm{LAK}$, FAK, D-FAK, HAK, D-HAK, PAK, D-EAK, $\mathrm{A}_{\mathrm{m}} \mathrm{K}(\mathrm{m}=8.5)$ vagy poli[Lys(Lys)], $\bullet=\mathrm{A}_{\mathrm{m}} \mathrm{K}(\mathrm{m}=3), \mathrm{o}=\mathrm{KAK}, \mathrm{D}-\mathrm{KAK}, \times=$ poli[Lys].

Az elágazó láncú polipeptidek metotrexáttal képzett konjugátumai - az alkalmazott polipeptid kémiai szerkezetétol függoen - igéretes Leishmania donovani intracelluláris parazita ellenes hatást mutattak. ${ }^{41} \mathrm{~A}$ makrofágokban fellelheto kórokozó perspektivikus eltávolítása érdekében kutatásaink során tanulmányoztuk a hordozóként alkalmazni kívánt polipeptidek citotoxicitását egér csontvelobol izolált makrofág sejteken tripánkék eljárást alkalmazva. ${ }^{15}$ Alacsony koncentrációban $(\mathrm{c}=1,0$ $\mu \mathrm{g} / \mathrm{ml}$ ) sem a poli[L-Lys], sem a polikationos vagy amfoter poli[Lys $\left.\left(\mathrm{X}_{\mathrm{i}}\right)\right]\left(\mathrm{X}_{\mathrm{i}} \mathrm{K}, \mathrm{X}=\right.$ His, Pro illetve Glu), sem pedig az XAK típusú polikationos (SAK,TAK), amfoter (EAK) vagy polianionos (Ac-EAK, Suc-EAK, Mal-EAK) vegyület nem mutatott toxikus hatást $\left(1\right.$ óra, $\left.37^{\circ} \mathrm{C}\right)$. Töményebb oldatban $(\mathrm{c}=20 \mu \mathrm{g} / \mathrm{ml})$, két $\mathrm{X}_{\mathrm{i}} \mathrm{K}$ típusú elágazó láncú $\left(\mathrm{P}_{\mathrm{i}} \mathrm{K}, \mathrm{H}_{\mathrm{i}} \mathrm{K}\right)$ és a lineáris a poli[L-Lys] polikationos vegyület csökkentette az élo sejtek számát (rendre 30\%, 80\% illetve 90\%-kal). ${ }^{\mathbf{1 5}, 42}$

Egy másik kísérletsorozatban e sejteket polikationos XAK $\left(\mathrm{X}=\right.$ Arg, Leu, Ile, Nle, Val), valamint $\mathrm{X}_{\mathrm{i}} \mathrm{K}(\mathrm{X}=\mathrm{Leu})$ polimer polipeptidekkel inkubáltuk ( 1 óra, $37^{\circ} \mathrm{C}, \mathrm{c}=0,6-100$ $\mu \mathrm{g} / \mathrm{ml})$. A citotoxicitás mértékét MTT módszer alapján az
$\mathrm{IC}_{50}$ értékkel jellemeztük. ${ }^{16}$ Azt tapasztaltuk, hogy az Arg tartalmú vegyület (RAK), amely az $\alpha-\mathrm{NH}_{2}$ csoport mellett guanidino csoportot is magában foglal $\left(\mathrm{IC}_{50}=17,9 \pm 5,4\right.$ $\mu \mathrm{g} / \mathrm{ml}$ ) és a polipeptid gerinchez közvetlenül kapcsolt leucint tartalmazó $\quad \mathrm{L}_{\mathrm{i}} \mathrm{K} \quad\left(\mathrm{IC}_{50}=121,2 \pm 21,9 \mu \mathrm{g} / \mathrm{ml}\right)$ polipeptidek citotoxikusak voltak. Ugyanakkor a szintén polikationos, hidrofób oldalláncú aminosavat és láncvégi $\alpha-\mathrm{NH}_{2}$ csoportot tartalmazó vegyületek (LAK, IAK, NleAK, VAK) nem okoztak sejtszám csökkenést a vizsgált koncentráció tartományban $\left(\mathrm{IC}_{50}>100 \mu \mathrm{g} / \mathrm{ml}\right) .{ }^{16}$

A következőkben Balb/c eredetü J774 monocita-makrofág sejtvonal sejtjeit kezeltük $\left(1,24\right.$ vagy 48 óra, $37^{\circ} \mathrm{C}, \mathrm{c}=$ 0,2-200 $\mu \mathrm{g} / \mathrm{ml}$ ) a polipeptidekkel és az élo sejtek számát MTT módszerrel határoztuk meg. ${ }^{39}$ Rövid inkubációt követően a legmagasabb koncentációban $(\mathrm{c}=200 \check{e} \mathrm{~g} / \mathrm{mL})$ a poli[Lys] $\left(\mathrm{LC}_{50}=65.7 \check{e} \mathrm{~g} / \mathrm{mL}\right)$, a polikationos $\mathrm{X}_{\mathrm{i}} \mathrm{K},(\mathrm{X}=\mathrm{His})$, valamint a polianionos Suc-EAK okozott sejtpusztulást (rendre $85 \%$ illetve $25 \%$ ). De sem a polikationos Pro, vagy amfoter Glu tartalmú $\mathrm{X}_{\mathrm{i}} \mathrm{K}$, sem az AK, sem az XAK tipusú polikationos (SAK, TAK), amfoter (EAK), polianionos (Ac-EAK) vegyületek nem bizonyultak toxikusnak. Hosszabb (24 óra) kezelést követoen a polikationos $\mathrm{X}_{\mathrm{i}} \mathrm{K}(\mathrm{X}$ $=$ Pro, His) és XAK (SAK, TAK), valamint az amfoter $\mathrm{X}_{\mathrm{i}} \mathrm{K}$ $(\mathrm{X}=\mathrm{Glu})$ és a polianionos Suc-EAK okozott jelentosebb (15-40\%) sejtpusztulást. ${ }^{39,42}$

A human HeLa carcinoma sejtek szaporodására gyakorolt gátló (citosztatikus) hatást az egyes polipeptidekre meghatározott $\mathrm{CT}_{0}(\mu \mathrm{g} / \mathrm{mL})$ értékkel $\left(3\right.$ nap, $\left.37^{\circ} \mathrm{C}\right)$ jellemeztük. ${ }^{23,24}$ Ennek alapján a polipeptideket három csoportba osztottuk: alacsony $\left(\mathrm{CT}_{0}>100 \mu \mathrm{g} / \mathrm{mL}\right)$, közepes $\left(10<\mathrm{CT}_{0}<100 \mu \mathrm{g} / \mathrm{mL}\right)$ és magas $\left(\mathrm{CT}_{0}<10 \mu \mathrm{g} / \mathrm{mL}\right)$ citosztatikus hatású vegyületek. Az amfoter polipeptideknek (pl. EAK) nem volt gátló hatásuk $\left(\mathrm{CT}_{0}>400 \mu \mathrm{g} / \mathrm{mL}\right)$, míg bizonyos polikationos vegyületek közepesen (AK) és az X (XAK) aminosavtól függően [X = (D)His, (D)Leu, (D)Phe, Pro] $\left(10<\mathrm{CT}_{0}<100 \mu \mathrm{g} / \mathrm{mL}\right)$ vagy erősen $[\mathrm{X}=(\mathrm{D}) \mathrm{Lys}]$ gátló hatásúnak bizonyultak $\left(\mathrm{CT}_{0}<10 \mu \mathrm{g} / \mathrm{mL}\right)$. Sem az X aminosav oldalláncbeli poziciója (pl. EAK/AEK, LAK/ALK) sem konfigurációja (pl. EAK/D-EAK, FAK/D-FAK, HAK/D-HAK, KAK/D-KAK) nem befolyásolta e besorolást. Megjegyzendő, hogy mind a poli- $\alpha$-lizin, mind pedig a poli- $\varepsilon$-lizin kifejezetten citosztatikusnak bizonyultak $\left(5 \mu \mathrm{g} / \mathrm{ml}<\mathrm{CT}_{0}\right){ }^{\mathbf{2 3 , 2 4}}$

C26 egér vastagbél carcinoma sejtek osztódására a poli- $\alpha$ lizin (poli[L-Lys]) markáns gátló hatást fejt ki (13. ábra). Az oligo(DL-Ala) oldallánc kiépítése [poli[Lys(DL-Ala $\left.\left.a_{m}\right)\right]$ $(\mathrm{AK})$, ahol $\mathrm{m}=6.5$ ] egy nagyságrenddel, míg a Ser aminosav megjelenése közvetlenül a poli[L-Lys] gerincen [poli[Lys $\left.\left(\operatorname{Ser}_{\mathrm{i}}\right)\right]\left(\mathrm{S}_{\mathrm{i}} \mathrm{K}\right)$, ahol $\left.\mathrm{i}<1\right]$ két nagyságrenddel csökkenti a citosztatikus hatást. A Ser poziciójának az oligopeptid oldalláncban jelentős befolyása van: láncvégi helyzetben (SAK) a vegyület nem citosztatikus, míg a polilizin gerinchez közeli pozicióban (ASK) az AK polipeptidhez mérhető gátló hatása van. ${ }^{\mathbf{1 2}}$ 


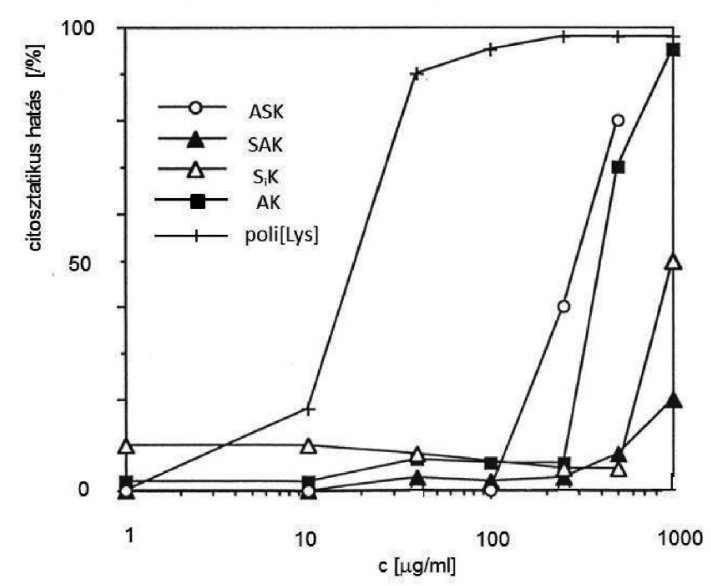

13. Ábra. A Ser tartalmú polipeptidek, továbbá a poli[L-Lys] és poli[Lys $\left.\left(\mathrm{DL}-\mathrm{Ala}_{\mathrm{m}}\right)\right](\mathrm{AK})($ ahol $\mathrm{m}=6,5)$ in vitro citosztatikus hatása $\mathrm{C} 26$ egér vastagbél carcinoma sejteken (inkubálás: 3 óra, $37^{\circ} \mathrm{C}$ ): $\mathrm{o}=\mathrm{ASK}$, $\boldsymbol{\Delta}=\mathrm{SAK}, \Delta=\mathrm{S}_{\mathrm{i}} \mathrm{K},($ ahol i $<1) \mathbf{\square}=$ AK és $\times=$ poli[Lys].

A polikationos polipeptidek HT-29 humán vastagbél carcinoma (ATCC HB-8065) illetve HepG2 humán hepatocelluláris carcinoma sejtvonalból származó sejtek osztódására gyakorolt hatását tanulmányoztunk. Az inkubálást követoen ( 1 óra, $37^{\circ} \mathrm{C}, \mathrm{c}=6,25-100 \mu \mathrm{g} / \mathrm{mL}$ ) az élo sejtek arányát MTT módszerrel meghatározva mindkét sejtpopuláción azt tapasztaltuk, hogy az AK, az XAK (X = Arg, Ser, vagy Thr) vagy AXK $\left(X=\right.$ Leu), illetve az $\mathrm{X}_{\mathrm{i}} \mathrm{K}(\mathrm{X}$ $=$ Leu, His vagy Pro) polimer polipeptidek nem befolyásolták a sejtek életképességét még az alkalmazott legnagyobb koncentrációban ( $\mathrm{c}=100 \mu \mathrm{g} / \mathrm{mL})$ sem. Ugyanakkor a poli[L-Lys] toxikusnak bizonyult mind a HT-29 $\left(\mathrm{LC}_{50}=44.1 \pm 4.6 \mathrm{ěg} / \mathrm{mL}\right)$, mind a HepG2 sejteken $\left(\mathrm{LC}_{50}=32.3 \pm 10.8 \mathrm{ěg} / \mathrm{mL}\right) .{ }^{40}$

Habár a citotoxikus/citosztatikus hatást nagyon különbözo sejteken vizsgáltunk, összefoglalásként érdemes felhívni a figyelmet arra, hogy az elágazó polipeptidek gerincét képezo poli[L-Lys] illetve az XAK (X= Lys) származék pusztító/gátló hatása jól megfigyelheto volt. Azok a polipeptidek, amelyek oldalláncaikban $\gamma$-karboxil (pl. EAK, Ac-EAK, AEK) vagy hidroxil (pl. SAK, ASK, TAK) csoportot hordoznak, azaz Glu, Ser vagy Thr aminosavat tartalmaznak nem mutattak markáns citotoxikus/citosztatikus hatást sem izolált patkány máj-, sem egér lép- vagy csontvelo eredetu sejteken, sem pedig a vizsgált különbözo sejtvonalak (J774, C26, HT-29 vagy HepG2) sejtjein.

\section{Szerkezet - in vivo plazmakoncentráció}

Az elágazóláncú polipeptidek szerkezete befolyásolja e vegyületek szöveti eloszlását, biodisztribúcióját.9,12,43 E kutatási program keretében radioaktív izotóppal jelzett polipeptideket intravénásan adtunk egészséges és tumort hordozó kísérleti állatoknak és azt tanulmányoztuk, hogy a különböző szerkezetü vegyületek milyen gyorsan távoznak a keringésből, mely szövetekben és milyen mértékben halmozódnak fel 24 óra után.
Az XAK típusú polikationos (AK), amfoter (EAK) és polianionos (Ac-EAK, Suc-EAK) polipeptidek jelölésére három különböző izotópot használtunk. A ${ }^{125} \mathrm{I}$ bevitele 3-(4-hidroxi-5-[ $\left.{ }^{125} \mathrm{I}\right]$ jódfenil)-propionsav- $N$-hidroxiszukcin -imid-észter (Bolton-Hunter reagens) segítségével történt ${ }^{\mathbf{4 3}}$, míg az ${ }^{111} \mathrm{In}$ vagy ${ }^{51} \mathrm{Cr}$ izotópok a polipeptidek kelátor (DTPA) származékával képeztek stabil komplexet. ${ }^{9,44} \mathrm{Azt}$ figyeltük meg, hogy a jelzett vegyületek keringésből történő távozására, annak kinetikájára az alkalmazott izotóp, a jelölés módja (kovalens vs komplex kötés) nincs markáns hatással. Megállapítottuk, hogy a szöveti eloszlást, szervekben (tumorban) való feldúsulás mértékét nagyban befolyásolhatja a választott izotópot tartalmazó vegyület metabolizmusa. ${ }^{46}$

Ugyanakkor a polimer polipeptid szerkezete jelentős mértékben meghatározza a konjugátumok keringésből történő távozását (14-16. ábrák). A polikationos sajátságú vegyületek (AK, LAK) gyorsan távoznak a keringésből (14.ábra).

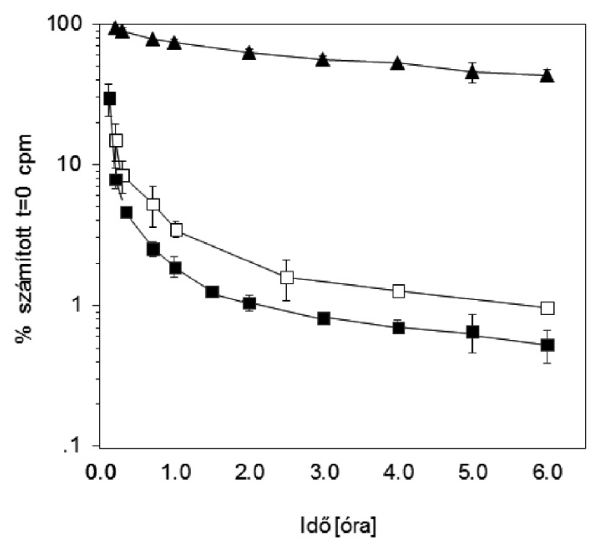

14. Ábra. $\mathrm{I}^{125}$ izotóppal jelölt amfoter (EAK) és polikationos (LAK, AK) polipeptidek távozása a vérkeringésből az idő függvényében. BALB/c egérek intravénás kezelése után: $\mathbf{\Delta}=\mathrm{EAK}, \mathbf{\square}=\mathrm{LAK}$ és $\square=\mathrm{AK}($ ahol $\mathrm{i}<1)$.

Ezzel szemben az amfoter karakterü polipeptid (EAK) lényegesen hosszabb ideig maradnak a vérkeringésben. Ezt a különbséget az X-aminosav konfigurációja (pl. LAK/D-LAK, EAK/D-EAK) érzékelhető módon nem befolyásolja ${ }^{43,46}$

Fontos megjegyezni, hogy a polikationos polipeptidek távozásának kinetikája függ az oldalláncban szerkezetétől, az $X$ aminosav jelenlététől, minemüségétől és az oldalláncban elfoglalt helyétől (15. ábra). Például a Leu (LAK) vagy Lys (KAK) tartalmú vegyület ${ }^{45}$ rövidebb ideig, a Ser tartalmú polipeptid (SAK) pedig hosszabb ideig és ebből adodóan 4 óra után különböző koncentrációban van jelen a keringésben (lásd 14. és 15. ábra). A hidroxil csoportot tartalmazó Ser közvetlenül a polipeptid gerinchez kapcsolódva $\left(\mathrm{S}_{\mathrm{i}} \mathrm{K}\right)$ gyorsan, míg az oligo(DL-Ala) egységgel kiegészített származék (ASK) lassabban távozik a vérkeringésből. Az oligopeptid $N$-terminálisán elhelyezett Ser variáns (SAK) pedig az injektált dózis közel 50\%-nak jelenléte mutatható ki egészséges egerek vérmintáiban. ${ }^{\mathbf{1 2}}$ 
Az amfoter polipeptidhez (EAK) hasonlóan viselkedik a polianionos, de monomer egységenként egyetlen negativ töltést hordozó polipeptid, az acetilezett EAK (Ac-EAK).

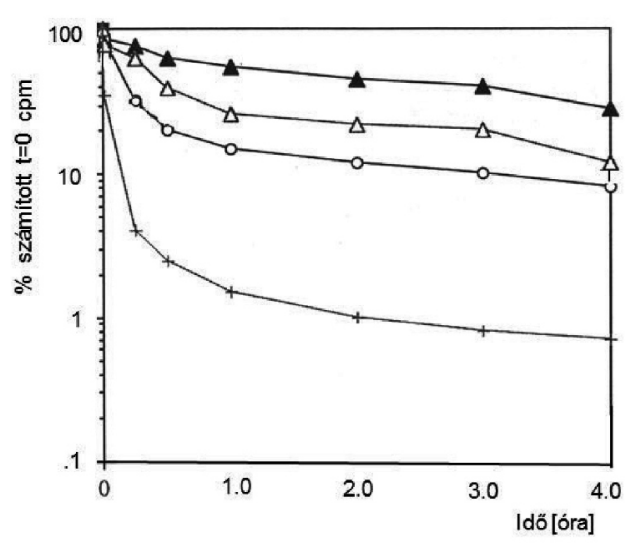

15. Ábra. $I^{125}$ izotóppal jelölt, Ser tartalmú polipeptidek és poli[ $\left.\operatorname{Lys}\left(\mathrm{DL}-\mathrm{Ala}_{\mathrm{m}}\right)\right](\mathrm{AK})(\mathrm{ahol} \mathrm{m}=3)$ távozása a vérkeringésből az idő függvényében. BALB/c egérek intravénás kezelése után: $\boldsymbol{\Delta}=\mathrm{SAK}, \mathrm{o}=$ ASK, $\Delta=\mathrm{S}_{\mathrm{i}} \mathrm{K},($ ahol $\mathrm{i}<1)$ és $+=\mathrm{AK}$.

Amennyiben egy polikationos vegyület (pl. AK) oligopeptid oldalláncának $\alpha$-amino csoportját acilezzük borostyánkősav anhidriddel ugyancsak polianionos, monomerenként egyetlen töltést hordozó származékhoz jutunk. E vegyületek (pl. Suc-AK, Suc-LAK) jelentősen hosszabb ideig tartozkódnak a vérkeringésben, mint az acilezés nélkül kiindulási vegyületek (pl. AK, LAK). ${ }^{9} \quad \mathrm{Az}$ $\mathrm{N}^{\alpha}$-aminocsoporton módosított amfoter EAK, amely így monomer egységenként két negatív töltést visel (Suc-EAK), távozása a keringésből jelentősen felgyorsul (16. ábra). ${ }^{45}$

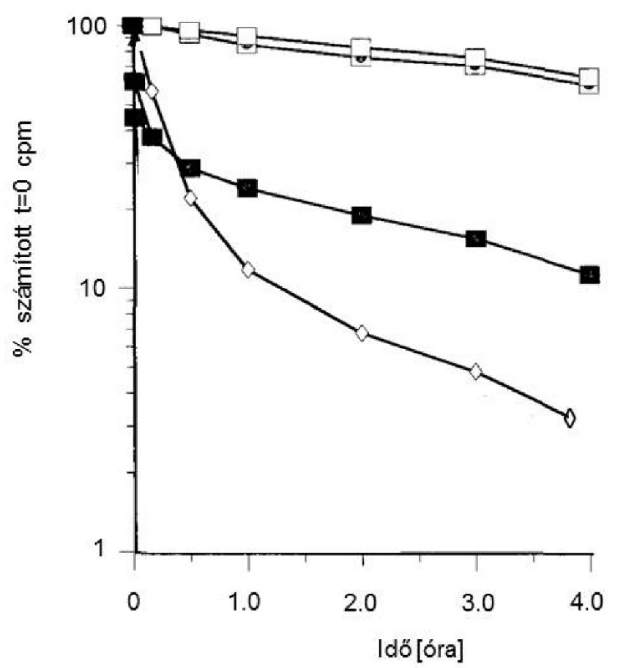

16. Ábra. In ${ }^{111}$ izotóppal jelölt XAK polipeptidek és poli[Lys(DL-Ala $\left.{ }_{m}\right)$ ] (AK) $($ ahol m=3,1) távozása a vérkeringésből az idő függvényében. $\mathrm{BALB} / \mathrm{c}$ egérek intravénás kezelése után: $\mathbf{\square}=\mathrm{EAK}, \diamond=$ Suc-EAK, $\square=$ Ac-EAK és $\mathbf{\square}=\mathrm{AK}$

Az eredményeket összegezve arra a következtetésre jutottunk, hogy a polimer polipeptidek véráramban való jelenlétének mértéke, ennek csökkenése és a vegyület kémiai szerkezete között szoros - elsősorban a vegyületek töltésével és a töltéssűrüséggel összefüggő - kapcsolat áll fenn. Az amfoter, illetve - az X aminosav oldalláncától függően bizonyos polikationos vegyületek ( $\mathrm{pl} . \mathrm{X}=$ Ser), valamint az egyszeres negatív töltéssel bíró polianionos vegyületek (pl. Ac-EAK) jelenléte a vérkeringésben markáns mértékben hosszabb, mint az oldalláncban $\mathrm{N}^{\varepsilon}$-aminocsoportot (pl. KAK) vagy kétszeres negatív töltést hordozó polipeptideké (pl. Suc-EAK). E megfigyelések érvényeseknek bizonyultak tumort hordozó egerek esetében is. ${ }^{46,47}$

\section{4. Összefoglalás és kitekintés}

A hazai és nemzetközi tudományos együttmüködésben feltárt összefüggések azt bizonyítják, hogy az elágazó láncú polimer polipeptidek kémiai szerkezet (aminosavösszetétel, oldallánc felépítés, aminosav konfiguráció) átgondolt módosításával előállítható olyan, különböző töltéssel rendelkező (pozitív/negatív/amfoter karakterü) vegyület, amely adott (pl. fiziológiás) körülmények között rendezett/ rendezetlen oldatbeli térszerkezet vesz fel. A feltárt, kémiai szerkezet és biológiai hatás, összefüggések alapján lehetőség nyilik olyan polipeptidek tervezésére is, amelyek in vitro citotoxicitása elhanyagolható mértékü és vérkeringésben a kívánt (hosszabb/rövidebb ideig van jelen. Állatkísérletekkel bizonyítottuk, hogy e polimerek vérkeringésből történő távozását, szervezetbeli eloszlását, sejttoxicitását töltésviszonyaik (pozitív/negatív, sürüség) nagymértékben befolyásolják.

Az előadásban bemutatott eredmények vezettek olyan, új biokonjugátumok tervezéséhez, előállításához és funkcionális jellemzéséhez, amelyekben tumorellenes (pl. daunomicin ${ }^{\mathbf{4 8 - 5 0}}$, hormon ${ }^{\mathbf{1 5 a}}$ ), antimikrobiális (pl. metotrexát 16,41,51) szer kapcsolódik makromolekuláris hordozóként alkalmazott elágazó láncú polipeptidhez, a hatásos vegyü-letek esetében a hatás mechanizmus tisztázásához (pl. a ,scavenger A” szerepének tisztázása).

\section{Köszönetnyilvánítás}

Az előadásban bemutatott eredmények, munkatársaim, a laborban dolgozó doktori hallgatók, diákok, valamint hazai (a szövegben említetteken kívül: Dr. Kajtár Judit, ELTE Szerves kémiai Tanszék, Dr. Kovács L. Attila, ELTE Állatszervezettani tanszék, Dr. Kurucz István, Gyógyszerkutató Intézet, Dr. Kőhidai László, SE Genetikai, Sejt- és Immunbiológiai Intézet) és nemzetközi (Dr. K. Blaha és Dr. H. Votavova, Institute of Organic Chemistry and Biochemistry, Prague; Prof. R. W. Baldwin, Dr. J. Clegg és Dr. M.V. Pimm, University of Nottingham; Prof. S.Gordon, Oxford University; Professor H. Maeda, Kumamoto University) partnerek munkáját tükrözik.

Köszönöm az MTA-ELTE Peptidkémiai Kutatócsoport munkatársainak, doktoránsainak a hatékony együttmüködést.

Köszönöm az MTA, az ELTE, az OTKA, valamint az MTA-CsTA (Magyar-Cseh), a TéT alapítvány (Magyar-Brit, Magyar-Japán) és EU-COST programok, ipari partnereink, Richter G. Nyrt, Reanal Rt és a többiek támogatását. 


\section{Hivatkozások}

1. Sela M. in: Polyamino Acids, Polypeptides and Proteins.(ed. Stahmann, M.A.) Univ Wisconsin Press, Madison, Wisconsin I962, 347- 358. https://doi.org/10.1016/S0065-3233(08)60614-2

2. Szekerke, M.; Wade, R.; Whisson, M.E. Neoplasma, 1972, 19, 199-209. https://doi.org/10.1016/0014-5793(74)80716-7

3. Hudecz, F.; Szekerke, M. Coll. Czech. Chem. Commun. 1980, 45, 933-940. https://doi.org/10.1135/cccc19800933

4. Hudecz, F.; Szekerke, M. Coll. Czech. Chem. Commun., 1985, 50, 103-113. https://doi.org/10.1135/cccc19850103

5. Hudecz, F.; Votavova, H.; Gaál, D.; Sponar, J.; Kajtár, J.; Blaha, K.; Szekerke, M. In: Polymeric Materials in Medication. (eds.: Gebelein, Ch.G., Carraher, Ch.E.,). Plenum Press, New York, 1985, 265-289.

6. Mező, G.;Votavova, H.; Hudecz, F.; Kajtár, J.; Sponar, J.; Szekerke, M. Coll. Czech. Chem. Commun., 1988, 53, 2843-2858. https://doi.org/10.1135/cccc19880903

7. Mező, G.; Hudecz, F.; Kajtár, J.; Szókán, Gy.; Szekerke, M. Biopolymers, 1989, 28, 1801-1826. https://doi.org/10.1002/bip.360281013

8. Mező, G.; Kajtár, J.; Hudecz, F.; Szekerke, M. Biopolymers, 1993, 33, 873-883. https://doi.org/10.1002/bip.360330603

9. Hudecz, F.; Kojima, Y.; Miyamoto, Y.; Kajtár, J.; Maeda, H. J. Controlled Release 1994, 28, 301-302 https://doi.org/10.1016/0168-3659(94)90189-9

10. Hudecz, F. Anti-Cancer Drugs 1995, 6: 171-193. https://doi.org/10.1097/00001813-199504000-00001

11. Mező, G.; Kajtár, J.; Nagy, I.; Szekerke, M.; Hudecz, F. Biopolymers, 1997, 42, 719-730. https://doi.org/10.1002/(SICI)1097-0282(199711)42:6<719: :AID-BIP9>3.0.CO;2-X

12. Hudecz, F.; Pimm, M.V.; Rajnavölgyi, É.; Mező, G.; Fabra, A.; Gaál, D.; Kovács, A.L.; Horváth, A.; Szekerke, M. Bioconjugate Chemistry, 1999, 10, 781-790. https://doi.org/10.1021/bc990015q

13. Mező, G.; Reményi, J.; Kajtár, J.; Barna, K.; Gaál, D.; Hudecz, F. J. Controlled Release 2000, 63, 81-95. https://doi.org/10.1016/S0168-3659(99)00175-3

14. Hudecz, F. In: Self-Assembling peptide systems in biology, medicine and engineering. (eds.: Agelli, A., Boden, N., Zhang, S.) Kluwer Academic Publisher,The Netherlands 2001, 139-160.

15. a) Mező G,; Mező, I.; Pimm, M. V.; Kajtár, J.; Seprődi, J.; Teplán, I.; Kovács, M.; Vincze, B.; Pályi, I.; Idei, M.; Szekerke, M.; Hudecz, F. Bioconjugate Chemistry, 1996, 7 , 642-650. https://doi.org/10.1021/bc9600574

b) Szabó, R.; Peiser, L.; Plüddemann, A.; Bősze, S.; Heinsbroek, S.; Gordon, S.; Hudecz, F. Bioconjugate Chemistry, 2005, 16, 1442-50. https://doi.org/10.1021/bc050168f

16. Sebestyén, M.; Szabó, R.; Kőhidai, L.; Pállinger, É.; Mező, G.; Kóczán, Gy.; Hudecz, F. Structural Chemistry, 2017, 28: 527-536. https://doi.org/10.1007/s11224-016-0901-z

17. Nagy, I.B.; Haro, I.; Alsina, A.; Reig, F.; Hudecz, F. Biopolymers, 1998, 46, 169-179. https://doi.org/10.1002/(SICI)1097-0282(199809)46:3<169: :AID-BIP4>3.0.CO;2-J

18. Nagy, I.B.; Majer, Zs.; Hudecz, F. Biopolymers, 2001, 58, 152-164. https://doi.org/10.1002/1097-0282(200102)58:2<152::AIDBIP40>3.0.CO;2-V
19. Hudecz, F.; Nagy, I.B.; Kóczán, Gy.; Alsina, M.A.; Reig, F. In: Biomedical polymers and polymer therapeutics. (eds.: Chiellini, E., Sunamoto, J., Migliaresi, C., Ottenbrite, R.M., Cohn, D.) Kluwer Academic/Plenum Publishers, New York 2001,103-120. Https://doi.org/10.1007/0-306-46842-5_9

20. Szabó, R.; Hudecz, F.; Reig, F. J. Colloid and Interface Science 2003, 267, 18-24. https://doi.org/10.1016/S0021-9797(03)00604-0

21. Nagy, I.B.; Hudecz, F.; Alsina M.A.; Reig, F. Biopolymers, 2003, 70, 323-335. https://doi.org/10.1002/bip.10494

22. Rajnavölgyi, E.; Hudecz, F.; Mező, G.; Szekerke, M.; Gergely, J. Mol.Immunol. 1986, 23, 27-37. https://doi.org/10.1016/0161-5890(86)90168-9

23. Rajnavölgyi, É.; Lányi, A.; Hudecz, F.; Kurucz, I.; Kiss, K.; László, G.; Szekerke, M.; Gergely, J. Molec. Immunol. 1989, 26, 949-958. https://doi.org/10.1016/0161-5890(89)90113-2

24. Hudecz, F.; Gaál, D.; Kurucz, I.; Lányi, S.; Kovács, A.L.; Mező, G.; Rajnavölgyi, É.; Szekerke, M. J. Controlled Release 1992, 19, 231-243. https://doi.org/10.1016/0168-3659(92)90079-7

25. Gaál, D.; Hudecz, F.;Szekerke, M. J. Biol. Resp. Modifiers, 1984, 3, 174-184. PMID:6547165

26. Gaál, D.; Hudecz, F.; Kovács, A.L.; Szekerke, M. J. Biol. Resp. Modifiers 1986, 5, 148-159. PMID:3525762

27. Gaál, D.; Hudecz F., Szekerke M. Eur. J. Cancer 1993 29A: Suppl. VI, S225. https://doi.org/10.1016/0959-8049(93)91882-L

28. Hudecz, F.; Kovács, P.; Kutassi-Kovács, S.; Kajtár, J. Colloid and Polymer Sci., 1984, 262, 208-212. https://doi.org/10.1007/BF01458962

29. Idei, M.; Dibó, G.; Bogdán, K.; Mező, G.; Horváth, A.; Érchegyi, J.; Mészáros, Gy. ;Teplán, I.; Kéri, Gy.;Hudecz, F. Electrophoresis 1996, 17,1357-1360. https://doi.org/10.1002/elps.1150170813

30. Schlosser, G.; Jakab, A.; Pocsfalvi, G.; Vékey, K.; Hudecz, F.; Mezö, G. Rapid Commun Mass Spectrom. 2009, 23,1249-1254. https://doi.org/10.1002/rcm.3993

31. Szókán, Gy.; Mező, G.; Hudecz, F. J. Chromatography, 1988 444, 115-122. https://doi.org/10.1016/S0021-9673(01)94014-2

32. Hudecz, F.; Kutassi-Kovács, S.; Mező, G.; Szekerke, M. Biol. Chem. Hoppe-Seyler, 1989, 370, 1019-1026. https://doi.org/10.1515/bchm3.1989.370.2.1019

33. Hudecz, F.; Dibó, G.; Kovács, P.; Szókán, Gy. Biol. Chem. Hoppe-Seyler, 1992, 373, 337-342. https://doi.org/10.1515/bchm3.1992.373.1.337

34. Votavova, H.;Hudecz, F.; Kajtár, J.; Szekerke, M.;Sponar, J.; Blaha, K. Coll. Czech. Chem. Commun., 1980, 45, 941-949. https://doi.org/10.1135/cccc19800941

35. Votavova, H.; Hudecz, F.; Sponar, J.; Szekerke, M.; Blaha, K. Coll. Czech. Chem. Commun., 1982 47: 3437-3446 (1982). https://doi.org/10.1135/cccc19823437

36. Votavova, H.; Hudecz, F.; Kajtár, J.; Sponar, J.; Blaha, K.; Szekerke, M. Coll. Czech. Chem. Commun., 1985, 50, 228-244. https://doi.org/10.1135/cccc19850228

37. Greenfield, N.J. Nat Protoc. 2006, 1, 2876-2890. https://doi.org/10.1038/nprot.2006.202

38. Greenfield, N.J.; Fasman G.D. Biochemistry. 1969, 8,4108-4116. https://doi.org/10.1021/bi00838a031

39. Szabó, R.; Mező, G.; Pállinger, É.; Kovács, P.; Kőhidai, L.; Bősze, Sz.; Hudecz, F. Bioconjugate Chemistry, 2008. 19, 1078-1088. https://doi.org/10.1021/bc7004544

40. Szabó, R.; Sebestyén, M.; Kóczán, Gy.;Orosz, Á.; Mező, G.; Hudecz, F. ACS Combinatorial Science, 2017,19, 246-254. https://doi.org/10.1021/acscombsci.6b00133 
41. Kóczán, Gy.; Ghose, A.C.; Mookerjee, A.; Hudecz, F. Bioconjugate Chemistry, 2002, 13, 518-524. https://doi.org/10.1021/bc015530e

42. Szabó, R. Ph.D. Disszertáció, 2005, Eötvös Loránd Tudományegyetem,

43. Clegg, J.A.; Hudecz, F.; Mező, G.; Pimm, M.V.; Szekerke, M.; Baldwin, R.W. Bioconjugate Chem., 1990, 1, 425-430. https://doi.org/10.1021/bc00006a009

44. Pimm, M.V.; Clegg, J.A.; Hudecz, F.; Baldwin, R.W. Int. J. Pharmaceutics 1992, 79, 77-80. https://doi.org/10.1016/0378-5173(92)90096-K

45. Pimm, M.V.; Gribben, S.J.; Mező,G.; Hudecz, F. J. Labelled Compd Radiopharm. 1995, 36, 157-172. https://doi.org/10.1002/jlcr.2580360208

46. Pimm, M.V.; Gribben, S.J.; Bogdán, K.; Hudecz, F. J. Controlled Release 1995, 37,161-172. https://doi.org/10.1016/0168-3659(95)00080-R
47. Pimm, M.V.; Hudecz, F. J. Cancer Res. Clin. Oncol. 1996, 122, 45-54. https://doi.org/10.1007/BF01203072

48. Gaál, D.; Hudecz, F. Eur.J.Cancer 1998, 34, 155-161. https://doi.org/10.1016/S0959-8049(97)00338-9

49. Reményi, J.; Csík, G.; Kovács, P.; Reig, F.; Hudecz, F. Biochim.Biophys. Acta 2006, 1758, 280-289. https://doi.org/10.1016/j.bbamem.2005.12.008

50. Szabó, R.; Bánóczi, Z.; Mező, G.; Láng, O.; Kőhidai, L. ; Hudecz, F. Biochimica et Biophysica Acta, 2010, 1798, 2209-2216. https://doi.org/10.1016/j.bbamem.2010.07.023

51. Díaz, E.; Köhidai, L.; Ríos, A.; Silva, A.; Vanegas, O.; Szabó, R.; Mező, G.; Hudecz, F.; Ponte Sucre, A. Experimental Parasitology 2013, 135, 134-141. https://doi.org/10.1016/j.exppara.2013.06.007

Influence of primary structure of branched chain polypeptides on solution conformation, in vitro cytotoxic/cytostatic effect and on in vivo blood clearance properties.

Despite numerous papers in the literature which include many encouraging results even in experimental and/or preclinical models, very few systematic studies were reported on structural and functional factors required for an optimal macromolecular carrier. To this end we have initiated investigation for establishing structure - function type correlation to facilitate rational design and/or selection of polymeric polypeptides as synthetic macromolecular carrier. We have prepared new groups of branched chain polymeric polypeptides with the general formula $\operatorname{poly}\left[\operatorname{Lys}\left(\mathrm{X}_{\mathrm{i}}-\mathrm{DL}-\mathrm{Ala}_{\mathrm{m}}\right)\right](\mathrm{XAK}), \operatorname{poly}\left[\operatorname{Lys}\left(\mathrm{X}_{\mathrm{i}}\right)\right]\left(\mathrm{X}_{\mathrm{i}} \mathrm{K}\right)$ and poly[Lys $\left(\right.$ DL-Ala $\left.\left.\mathrm{m}_{\mathrm{i}} \mathrm{X}_{\mathrm{i}}\right)\right](\mathrm{AXK})$ where $\mathrm{i}<1, \mathrm{~m} \sim 3$, and $\mathrm{X}$ represent an additional optically active D- or L-amino acid residue. These polymeric polypeptides were characterized by their size, chemical (primary structure, solution conformation) and biological (in vitro cytotoxicity, pyrogenicity, biodegradation, immunoreactivity and biodistribution) properties. In this communication a brief outline is provided concerning the synthesis, structural analysis with a special emphasis on solution conformation new the above three sets of polymeric polypeptides. In addition two aspects related to biological properties, namely in vitro cytotoxic/cytostatic effect on isolated rat liver, mouse spleen and mouse bone-marrow cells as well as on various cell lines (J774, C26, HepG2, HT-29) and blood clearance after i.v. injection of ${ }^{125} \mathrm{I},{ }^{111} \mathrm{In}$ or ${ }^{54} \mathrm{Cr}$ labelled polypeptides. In all three chapters the focus of the discussion is on the correlation between primary structure (amino acid composition, side chain structure, charge properties) and the solution conformation studies by CD spectroscopy, cell viability/inhibition and blood clearance/survival. We report here that the formation of ordered conformation in solution could be well designed by the appropriate intramolecular secondary linkages (e.g. ionic, H-bond and/or hydrophobic) between the branches. This can be achieved by the nature, configuration and position of amino acid $\mathrm{X}$. The in vitro cytotoxic/cytostatic effect of the polypeptide as well as the in vivo blood clearance properties are predominantly determined by the charge of the compounds. High positive or negative charge density could result in marked cytotoxicity/cytostasis and quick and efficient disappearance of the polypeptide from the blood circulation. 